\title{
PENGEMBANGAN KOORDINASI MATA DAN TANGAN ANAK USIA TAMAN KANAK-KANAK
}

\author{
Vanny Mutia May Andry ${ }^{1}$ Yaswinda $^{2}$ \\ PG PAUD Fakultas Ilmu Pendidikan, Universitas Negeri Padang ${ }^{1,2}$ \\ Email:vannymutia1905@gmail.com¹, yaswinda@fip.unp.ac.id ${ }^{2}$ \\ Andry, Vanny Mutia May., Yaswinda. (2021). Kajian Literatur Pengembangan Koordinasi Mata dan \\ Tangan Anak Usia Taman Kanak-Kanak. Jurnal Pelita PAUD, 6(1), 110-117 \\ doi: https://doi.org/10.33222/pelitapaud.v6i1.1440
}

Diterima:28-09-2021

Disetujui: 19-11-2021

Dipublikasikan: 24-12-2021

\begin{abstract}
Abstrak: Penelitian ini bertujuan untuk bagaimana melihat konsep, kegiatan/ permainan, serta manfaat pengembangan dalam koordinasi mata dan tangan terhadap pembelajaran anak usia Taman Kanak-Kanak. Penelitian ini berawal pada bagaimana koordinasi mata dan tangan pada pembelajaran anak. pengembangan koordinasi mata dan tangan anak belum berkembang secara optimal. dalam proses pembelajaran yang dilakukan pengembangan koordinasi mata dan tangan anak sangat penting untuk dikemabngkan, karena dengan mengembangkan koordinasi mata dan tangan pada anak dengan baik maka anak akan melakukan kegiatan sehari-hari dengan lancar dan tanpa kendala apapu. Penelitian ini menggunakan metode kualitatif dengan kajian literatur. Pengumpulan data yang digunakan dengan menelaah sumber-sumber yang relevan berupa artikel, jurnal dan lainnya menggunakan teknik analisis isi. Hasil dari penelitian adalah dari beberapa pengembangan dengan menggunakan berbagai macam kegiatan guru dapat mengembangkan koordinasi mata dan tangan anak dengan baik dan benar.

Kata Kunci: Koordinasi Mata-Tangan, Anak Usia Dini.
\end{abstract}

Abstract: This study aims to see how concepts, activities/games, as well as the benefits of developing hand-eye coordination on the learning of Kindergarten age children. This research begins with how hand-eye coordination is in children's learning. The development of eye and hand coordination inchildren has not developed optimally. In the learning process, the development of eye-hand coordination in children is very important, because by developing good eye and hand coordination, children will carry out daily activities smoothly and without any obstacles. This study uses a qualitative method with a literature review. Data collection is used by examining relevant sources in the form of articles, journals and others using content analysis techniques. The results of the research are from several developments using various kinds of teacher activities to develop children'seye and hand coordination properly and correctly.

Keywords: Hand-Eye Coordination, Early Childhood.

(C) 2021 Vanny Mutia May Andry, Yaswinda. Under the license CC BY-SA 4.0

http://jurnal.upmk.ac.id/index.php/pelitapaud 


\section{PENDAHULUAN}

Pendidikan Anak Usia Dini ialah satu wujud pembelajaran yang menitik berat pada dasar perkembangan serta pertumbuhan agama serta moral, raga koordinasi motorik halus serta agresif, bahasa, kognitif, sosial emosional serta seni.. Bagi (Hasan, 2011), anak dibina dengan pemberian rangsangan pendidikan buat membantu pertumbuhan dan perkembangan jasmani dan rohani biar anak memiliki kesiapan dalam pendidikan lebih lanjut, baik itu jalur formal maupun nonformal, melalui PAUD. (Risaldy dan Meity, 2014) Pendidikan anak usia dini merupakan hal mendasar yang dilakukan sedini mungkin dan dilaksanakan secara menyeluruh dan terpadu. Aspek nilai agama serta moral, raga motorik, bahasa, kognitif, sosial emosional, serta seni yang wajib dibesarkan dalam PAUD telah diatur dalam Peraturan Mentri Nasional PAUD, ialah aspek nilai agama serta moral, fisi Pertumbuhan raga motorik merupakan salah satu bidang pengembangan yang sangat berarti buat dibesarkan semenjak dini.

Raga motorik anak dibagi atas 2 ialah motorik kasar serta motorik halus. Keahlian motorik kasar ialah berjalan, melompat, meloncat, berbalik, serta sebagainya yang mengaitkan pemakaian gerak badan besar serta raga. Menggambar, menulis, meronce, memberi warna, menjahit, mengayam, kolase merupakan keahlian motorik halus(Martinis \& Sanan, 2010). Pertumbuhan motorik halus merupakan pertumbuhan gerakan anak yang memakai otot kecil ataupun sebagian anggota badan tertentu dengan dipengaruhi oleh peluang anak buat belajar serta berlatih (Sumantri, 2011). Kemampuan motorik halus sangat berguna bagi anak untuk menyelesaikan kegiatan dalam kehidupannya terutama yang berkaitan dengan keterampilan. Kemampuan motorik halus anak juga akan membantu kemampuan yang lainnya seperti:kogntif, bahasa, sosial emosional, dan lainnya. Hal ini karena dalam melakukan kegiatan atau keterampilan membutuhkan ketelitian, konsentrasi, kesabaran serta kreativitas. Anak memiliki kemampuan motorik halus dengan waktu yang lebih cepat serta memiliki krativitas dalam karyanya. Meningkatkan halus motorik keahlian sangat bermanfaat untuk anak buat menuntaskan aktivitas dalam kehidupannya, paling utama keahlian. Pengembangan motor keahlian halus hendak menolong serta melatih anak supaya terampil memakai tangan serta jemari dan koordinasi mata dengan balance. Karakteristik pengembangan motorik halus anak lebih ditekankan pada gerakan-gerakan tubuh yang lebih spesifik seperti menulis, menggambar, menggunting dan melipat (Santoso, 2005). Kemapuan koordinasi merupakan salah satu komponen dalam gerak dasar. Tolak ukur keahlian koordinasi ditunjukkan pada ketetapan anak dalam menunjukkan keahlian motorik pada target/ sasaran tertentu, keahlian koordinasi ditunjukkan pada ketetapan anak dalam menunjukkan keahlian motorik (Sukadiyanto, 2018). Koordinasi mata serta tangan ialah gerakan yang sangat dibutuhkan supaya pekerjaan/ activitas bisa terselesaikan dengan baik, mudah, serta berentetan dan cocok dengan kemauan.. Pada realitasnya, kesusahan bertambah pada pertumbuhan motorik halus anak spesialnya pada koordinasi mata serta tangan pada umur halaman anak- anak secara totalitas masih belum tumbuh (Saputra \& Ridyanto, 2017). Latihan koordinasi dapat dikembangkan sejak usia dini karena pada usia ini anak lebih cepat menyerap informasi yang diberikan sehingga lebih mudah dalam melaksanakan apa yang diajarkan guru. Anak yang memiliki koordinasi yang baik akan memiliki gerak yang luwes, lancar, mudah dan harmonis dalam melakukan aktivitas motorik. Koordinasi mata dan tangan yang baik memiliki manfaat bagi kehidupan anak untuk dapat mengurus dirinya, mencapai tujuan, dan keterampilan hidup, seperti: mengacingkan baju, menali sepatu, dan bebrbagai aktivitas lain yang berkaitan dengan koordinasi mata dan tangan.

Terdapatnya keterlambatan dalam keahlian koordinasi mata serta tangan, sebagian anak mempunyai koordinasi yang belum maksimal ataupun dengan kata lain berketeria belum tumbuh. Perihal tersebut nampak dari metode anak memegang alat- alat tersebut dalam jangka waktu yang lam, sehingga dalam aktivitas semacam mencocok, memberi warna, serta menulis hasilnya belum apik. Keahlian buat mengkoordinasi gerak mata serta tangan masih renda, kasus di atas bisa diakibatkan oleh sebagian aspek, antara lain jari- jari tangan anak belum lemas, minimnya keahlian anak buat mengulangi kembali, anak kurang memperoleh stimulasi, serta khawatir buat melaksanakan gerakan yang rumit. Pada kenyataannya, kesulitan meningkat pada perkembangan motorik halus khususnya Pada koordinasi mata dan tangan. Pengamatan yang peneliti lakukan, untuk pengembangan motoric halus anak dalam koordinasi mata dan tangan anak usia taman kanak-kanak secara keseluruhan masih belum berkembang secara lancar. Adanya keterlambatan dalam kemampuan koordinasi mata dan tangan anak. Beberapa anak memiliki koordinasi mata dan tangan yang belum optimal ataudengan kata lain berketeriabelum berkembang. Meningkatkan koordinasi mata serta 
tangan anak sangatlah berarti sebab dalam melaksanakan aktivitas buat meningkatkan motorik halus anak. Bagi Marzila( melaporkan keahlian motorik halus anak merupakan kegiatan motorik yang mengaitkan otot- otot kecil ataupun halus yang gerakannya lebih menuntut koordinasi mata serta tangan dan mengaitkan koordinasi syaraf otot. Dengan demikian, koordinasi mata serta tangan sangatlah mempengaruhi serta keterkaitan kepada kegiatan yang anak laksanakan semacam meremas, melekat, memasang kancing, mengikat sepatu serta sebagainya. Di dalam penelitian ini bertujuan untuk melihat bagaimana konsep koordinasi mata dan tangan anak, seperti apa kegiatan/ permainan koordinasi mata dan tangan anak usia taman kanak-kanak serta bagaimana manfaat pengembangan koordinasi mata dan tangan anak taman kanak-kanak.

Dari uraian di atas, bisa disimpulkan periset kalau dalam melaksanakan aktivitas buat pengembangan motorik halus anak hendak dicoba dalam koordinasi mata serta tangan anak, aktivitas yang dicoba semacam mengayam, melipat kertas, meronce, serta lain- lain. Riset ini bertujuan buat memandang gimana konsep, aktivitas/ game, dan khasiat dalam pengembangan koordinasi mata serta tangan anak umur Halaman Anak- anak.

\section{METODE PENELITIAN}

\section{Jenis Penelitian}

Jenis penelitian yang digunakan adalah studi literatur dengan menelaah jurnal, buku dan skripsi yang terkait dengan rumusan masalah. Studi pustaka atau riset pustaka yang objek penelitiannya dapat ditelusuri di berbagai hasil karya ilmiah di pustaka atau medial lain (Muslim, dkk. 2018). Studi literatur merupakan sebuah penelitian yang mana data didapat dengan cara meneliti dan memahami buku-buku, dokumen atau sumber tertulis lainnya. Riset pustaka memanfaatkan sumber perpustakaan untuk memperoleh data penelitian, dimana riset pustaka membatasi kegiatannya hanya pada bahan-bahan koleksi perpustakaan saja tanpa memerlukan riset lapangan. Studi pustaka suatu kerangka ilmiah yang berisi pendapat berbagai pakar mengenai suatu masalah yang kemudian ditelaah dan dibandingkan sertaditarikkesimpulannya. Pada penelitian berusaha melihat bagaimana pengembangan motorik halus anak dalam koordinasi mata dan tangan anak usia Taman Kanak-Kanak.

\section{Data, Instrumen, dan Teknik Pengumpulan Data}

Data merupakan sekumpulan informasi atau kerangka-kerangka yang diperoleh dari pengamatan, informasi itu bisaberupaangka, lambing, maupun sifat. Data yang digunakan dalam penelitian adalah data kualitatif. Data merupakan suatu fakta akurat yang dikumpulkan untuk kepentingan dalam pemecahan masalah atau untuk menjawab pertanyaan penelitian, yang berasal dari berbagai sumber yang dikumpulkan dengan menggunakan berbagai teknik dalam kegiatan penelitian itu berlangsung. Dari data kualitatif, data yang berbentuk kata-kata maupunkalimat, yang bukan dalam bentuk angka atau perhitungan. Jenis data yang digunakandalampenelitianadalah data sekunder. Dengan menggunakan data sekunder sumber data yang diperoleh secara tidak langsung.data tersebut di dapatkan dari dokumen-dokumen yang berkaitan dengan penelitian. Data iniberupa: catatan atau laporan historis yang telah tersusun dari dalam dokumen. Sumberdata dalam penelitian ini menggunakan sumber acuankhusus yang berupa jurnal, artikel, sertadokumendokumen yang berkaitan dengan penelitian yang dilakukan. Teknik pengumpulan data yang digunakan dalam penelitian ini dengan studi literature. Pengumpulan data dapat dilakukan dalam berbagai settingan, berbagai sumber, dan berbagai cara.Dalam mengumpulkan datanya dari sumber-sumber yang relevan, serta mendukung terhadap penelitian yang akandikaji dengan menggunakan data sekunder yaitu data yang diambil dari dokumen-dokumen yang memuat informasi untuk keberlangsungan proses penelitian.

\section{Teknik Analisis Data}

Teknik analisis data yang digunakan dalam penelitian studi literatur ini menggunakan metode analisis isi (content Analysis).Teknik analis data yang digunakan dalam penelitian kepustakaan bisa dengan menggunakan metode anilisis (content Analysis). Analisis isi dapat digunakan untuk menganalisa semua bentuk komunikasi yang lainnya. Teknik analisis isi,menyatakan analisis adalah sebuah alat penelitian yang difokuskan pada konten actual dan fitur internal media.Dalam analisis ini akan dilakukan proses, memilih, membandingkan, menggabungkan, memilah berbagai pengertian, hingga ditemukan yang relevan.

\section{HASIL DAN PEMBAHASAN}

Anak usia dini memiliki perkembangan dalam aspek perkembangan yaitu kogntif, bahasa, sosialemosional, kreativitas dan fisik motorik. Dalam 
proses pembelajaran guru perlu adanya sebuah konsep dalam aspek perkembangan anak salah satunya dalam aspek motorik halus pada koordinasi mata dan tanganya. Menurut (Darmastuti, 2012) motorik halus berhubungan dengan bagian- bagian badan tertentu serta dicoba otot- otot kecil, membutuhkan koordinasi yang teliti semacam mengamati suatu, menjepit, menulis, serta yang lain.

\section{Konsep Koordinasi Mata dan Tangan}

Konsep ialah penafsiran, cerminan mental dari objek, proses, komentar, rancangan yang sudah dipikirkan. Supaya seluruh aktivitas berjalan dengan sistematis serta mudah, diperlukan sesuatu perencanaan yang gampang dimengerti serta dipahami. Maka, konsep koordinasi mata dan tangan merupakan suatu gambaran atau rancangan guru untuk membuat suatu proses pembelajaran yang akan dilakukan, dalam kegiatan pembelajaran guru terlebih dahulu memikirkan seperti apa konsep yang akan dilakukan disaat proses kegiatan pembelajaran dalam pengembangan koordinasi mata dan tangan anak. dari penjelasan di atas dari beberapa artikel yang didapat yang akan di analisis melalui tabel diantaranya; Menurut (Safdin \&Mansor, 2010) perkembangan koordinasi mata dan tangan anak 'kesediaan' di Prasekolah konsep yang dilakukan dengan menggunakan kegiatan menulis. Dengan kegiatan disini guru mendapatkan konsep dalam pengembangan koordinasi mata dan tangan anak dalam proses pembelajaran. Menurut (Marselina, 2018)dengan menggunakan metode melipat kertas (origami) yang digunakan tentunya adalah salah satu bentuk kegiatan yang menggunakan kemampuan otot tangan serta koordinasi mata. Dengan kegiatan ini ditemukan bahwa penelitian menggunakan kegiatan ini dalam pembelajaran yang akan diberikan.

Sejalan dengan temuan pendapat di atas, Bagi (Agusmiati, 2019) pemberian aktivitas bermain kolase bisa tingkatkan koordinasi mata serta tangan pada anak di Halaman Anak- anak, dengan aktivitas ini periset menciptakan konsep dalam pengembangan koordinasi mata serta tangan anak. tak hanya itu, (Rofiah \& Mangkuwibawa, 2020) dalam penelitian ini peneliti mengembangkan koordinasi mata dan tangan pada anak dengan menggunakan kegiatan membatik jumputan yang dimana permainan ini adalah salah satu pengamatan terhadap anak diantaranya kelenturan, koordinasi mata dan tangan anak, serta ketepatan anak dalam melakukan kegaiatan tersebut dengan benar.
Berdasarkan dari urain di atas dapat disimpulkan dengan kegiatan kolase, mebantik jumputan, serta menulis merupakan sebuah konsep dalm pengembangan koordinasi mata dan tangan anak yang dilakukan dalam proses kegiatan pembelajaran.

\section{Kegiatan/ Permainan Koordinasi Mata dan Tangan}

Kegaiatan/ permainan merupakan hal yang penting bagi anak. kegiatan/ permainan menjadi salah satu cara untuk membantu mengembangkan berbai kegiatan aspek pada anak usia dini. Menurut (Rosulillah, 2019)dengan menggunakan permainan montase dapat mengembangkan koordinasi mata dan tangan, karena dengan permainan ini guru mengajak anak untuk menggunting dan menyusun kembali menjadi sebuah cerita. Dalam melakukan permainan ini rentang usia pada permain montase usia 4-5 tahun lebih mengarahkan pada tingkat pencapaian gerak mata dan tangan dengan melakukan gerakan yang rumit. Dengan kegiatan menggunting berbagai macam media dapat mengembangkan koordinasi mata dan tangan anak karena dengan menggunaka kegiatan ini anak tidak akan cepat bosan serta dengan media menggunting dapat meningkatkan mata dan tangan anak (Whinda, 2014). Sejalan dengan beberapa artikel, jurnal dan dokumen yang mendukung. Menurut (Dan et al., 2020) dengan menggunakan kegiatan kolase dapat meningkatkan koordinasi mata dan tangan pada anak, karena dengan permainan kolase adalah teknik menempel berbagai macam unsur kedalam satu frame sehingga menghasilkan karya seni yang baru. Dan menurut (Durotun Nihayah, 2019) dengan menggunakan media papan pasak mampu memberikan pemahaman pengenalan huruf pada anak, guru yang menggunakan strategi pembelajaran papan pasak dengan media papan pasak tepat, baik dalam kemampuannya dan kesesuaian dengan materi dalam penyampaiannya. Tidak hanya pada pengenalan huruf dengan permainan ini juga dapat mengembangkan kemampuan koordinasi mata dan tangan pada anak. implementasi media pembelajaran ini dapat diterapkan pada anak usia 3-4 tahun, pada rentang usia anak ini anak lebih suka bermain dari pada belajar, dan guru memadukan permainan dan pembelajaran. Media papan pasak adalah salah satu media yang menggunakan media yaitu media gambar, dengan menggunakan media gambar, diharapkan anak menjadi lebih termotivasi dan membantu peserta didik dalam membangkitkan imajinasi dalam belajar. Papan pasak adalah media pembelajaran yang membelajarkan anak terhadap permasalahan 
yang ada disekitarnya melalui analisis contohcontoh berupa gambar/foto/kasus yang bermuatan masalah.

Pada permainan papan pasak ini melakukan pengenalan huruf hijaiyah pada anak, dalam hal ini yang menjadi target utama yaitu untuk melatih koordinasi mata dan tangan anak didik dalam menyusun huruf hijaiyah pada papan pasak.Menurut (Riza Armita Putri, 2019) melalui permainan lempar tangkap bola dapat meningkatkan koordinasi gerak mata dan tangan anak. Rentang usia pada permainan ini adalah anak usia 3-6 tahun, pada masa ini merupakan masa peka yang sangat rentan terhadap berbagai pengaruh dari luar, baik fisik, mental, emosi maupun sosial. Dengan memahami mereka, maka guru dan orangtua dapat memberikan bantuan yang sesuai dengan kebutuhan perkembangannya, salah satu perkembangan fisik yang dialami oleh anak usia dini adalah kemampuan koordinasi gerak mata dan tangan. Kemampuan koordinasi gerak mata dan tangan sangat penting bagi kelangsungan kehidupan anak dikemudian hari. Karena kemampuan koordinasi gerak mata dan tangan adalah suatu integrasi antara mata sebagai pemegang fungsi utama dan tangan sebagai pemegang fungsi melakukan suatu gerakan tertentu. Koordinasi mata dan tangan sangat diperlukan, apalagi bagi anak berumur 5-6 tahun perlunya koordinasi mata dan tangan ini ialah agar terjadi organisasi yang baik antara tangan dan mata. Akan tetapi, sebagai guru di SLB kurang memperhatikan perkembangan koordinasi mata dan tangan anak, padahal koordinasi gerak mata dan tangan ini sngat diperlukan karena selalu berhubungan dengan kegiatan sehari-hari seperti memasang mutemute, meronce, memasang kancing baju, memasang tali sepatu, menghubungkan titik-titik, menuang air dari teko ke dalam kertas dam lain-lain. Dari 10 anak usia 5-6 tahun menunjukkan terdapat dua anak yang mengalami hambatan kemampuan koordinasi mata dan tangan. hal tersebut dibuktikan dengan anak yang tidak dapat melakukan kegiatan seperti meronce, mengguntig, merobek kertas berpola, menghungkan titik-titik, dan melempar tangkap bola. Maka, dapat disimpulan bahwa anak masih mengalami koordinasi mata dan tangan. Sejalan dengan pendapat di atas, Menurut (Rika Vira Zwagery, 2013) dengan menggunakan permainan Attack The Shark dapat meningkatkan kemampuan koordinasi mata dan tangan pada anak. "Attack the Shark" yang dimana permainan ini berbentuk seperti sebuah arcade game pada tempat bermain pada umumnya seperti timezone dan amazone namun dibuat compact dengan menggunakan bahan 90\% kardus sebagai bahan utama sehingga sangat mudah untuk didapat dan dibuat. Permainan ini dimainkan dengan cara menarik dan mengulur tali yang berada pada kiri dan kanak permainan, yang berfungsi untuk menyeimbangkan kelereng yang berada di atas perahu. Tujuan atau pencapaian utama permainan ini adalah, permainan harus mampu untuk melewati lubang-lubang yang berada di permainan untuk sampai ke lubang finish. Dalam permainan ini perlu adanya kesabaran dan ketepatan dalam menarik dan mengulur tali agar kelereng tidak masuk ke dalam lubang perangkap yang membuat permainan harus diulang kembali dari awal. Maka, dalam permainan ini tidak hanya mengembangkan koordinasi mata dan tangan anak tetapi juga mengembangkan emosional pada anak. rentang usia yang dapat dilakukan pada permainan ini anak usia 5-6 tahun.

Dalam penelitian ini, beberapa anak memiliki perkembangan dan pertumbuhan yang berbedabeda dan ciri-ciri yang berbeda seperti anak cerebral plasy spastik atau bisa disebut dengan anak berkebutuhan khusus. Dalam kasus ini tentunya anak berkubutuhan khusus perlu pengembangan yang dapat meningkatkan aspekaspek perkembangan yang terlambar. Salah satunya pada perkembangan koordinasi mata dan tangannya, anak cerbral memiliki keterbatasan akan kegiatan-kegiatan yang terkait dengan mata dan tangannya. Menurut (Malika \& Sutisna, 2017) dengan melakukan permaina kirigami dapat meningkatkan koordinasi mata dan tangan pada anak Cerebral Plasy Spastik, dimana anak diajak untuk menggunting kertas.

Maka dapat disimpulkan dari uraian di atas, anak berkebutuhan khusus sangat perlu dalam aspek perkembangannya khususnya pada koordinasi mata dan tangan. maka anak normal pun juga membutuhkan pengembangan koordinasi mata dan tanganya dengan menggunakan beberapa kegiatan/ permainan yang menyenagkan dan bervariasi, dengan menggunakan arahan dan perhatian yang sama dan cara yang bagus, sempurna dan menyenangkan.

\section{Manfaat Pengembangan Koordinasi Mata dan Tangan}

Dalam kegiatan/ permainan yang telah diterapkan atau diberikan kepada anak dalam proses kegiatan pembelajaran memiliki sebuah manfaat dakam kegiatan tersebut. Mafaat adalah suatu hal yang memiliki nilai guna yang dapat memberikan hasil atau faedah. Bagi (Rasid et al., 2020) dengan aktivitas cooking class, khasiat diataranya; 1 . Bisa meningkatkan ekspresi lewat bermacam media 
dengan gerakan tangan, 2. Bisa meningkatkan fantasi, imajinasi, jari- jemari, koordinasi otot serta otot serta mata, 3. Melatih kecakapan mengombinasikan warna, 4. Membuktikan perasaan terhadapa gerakan tangan. Menurut (Tasnila, 2012) dengan kegiatan/ permainan menelujur baju yang dilakukan, manfaat diantaranya; 1 . Dapat mengembangkan koordinasi mata dan tangan anak, 2. Anak mampu menyelesaikan pekerjaan sehari-hari dengan baik, lancar dan benar. Selajan dengan pendapat di atas, Menurut (Rosulillah, 2019) dengan menggunakan kegiatan/ permainan Montase, manfaat diantaranya; 1. Dapat mengembangkan kreativitas, estetika, dan daya sepa anak, 2. Mengembangkan koordinasi mata-tangan, 3. Mengontrol emosional pada anak. (Durotun Nihayah, 2019) menggunakan permainan papan pasak, manfaat di antaranya; 1. Dapat mengembangkan koordinasi mata dan tangan anak, 2. Dapat mengembangkan membaca anak, 3 . Mengembangkan kretifitas anak, 4. Mengembangkan moral dan agama pada anak. selajan dengan pendapat pendapat di atas, menurut (Rika Vira Zwagery, 2013) dengan menggunakan permainan Attack the Shark, manfaat diantaranya; 1. Dapat mengembangkan emosional pada anak, 2.Dapat mengembangkan koordinasi mata dan tangan anak, mengembangkan kreativitas anak, 3 . Dapat mengembangkan imajinasi yang dimiliki oleh anak. sejalan dengan manfaat oleh para peneliti diatas, menurut (Malika \& Sutisna, 2017) dengan melakukan permainan kirigami manfaat yang didapatkan dalam permainan tersebut: 1 . Dapat meningkkatkan konsetrasi anak dalam menyelesaikan kegitan permainan, 2. Dapat mengembangkan koordinasi mat a dan tangan anak, 3. Dapat mengembangkan rasa percaya diri pada anak.

Dari analisis hasil dan pembahasan penelitian, dapat ditarik kesimpulan, bahwa konsep koordinasi mata dan tangan anak, kegiatan/permainan serta manfaat pengembangan koordinasi mata dan tangan dapat dikembangkan dengan beberapa kegiatan. Karena dengan kegiatan tersebut seperti; montase, kolase, origami, puzzle magneticeria dapat mengembangkan koordinasi mata dan tangan. dari kegiatan/permainan tersebut tidak hanya mengembangkan koordinasi mata dan tangan anak, tetapi juga dapat mengembangkan beberapa aspek seperti: mengembangkan kognitif anak, kreativitas, daya ingat pada anak, mengontrol emosional pada anak dan sebagainya, mengembangkan imajinasi anak, mengembangkan kepercayaan diri anak untuk melakukan sebuah kegiatan yang telah diberikan oleh gurunya.

Tabel 1. Temuan Hasil Penelitian

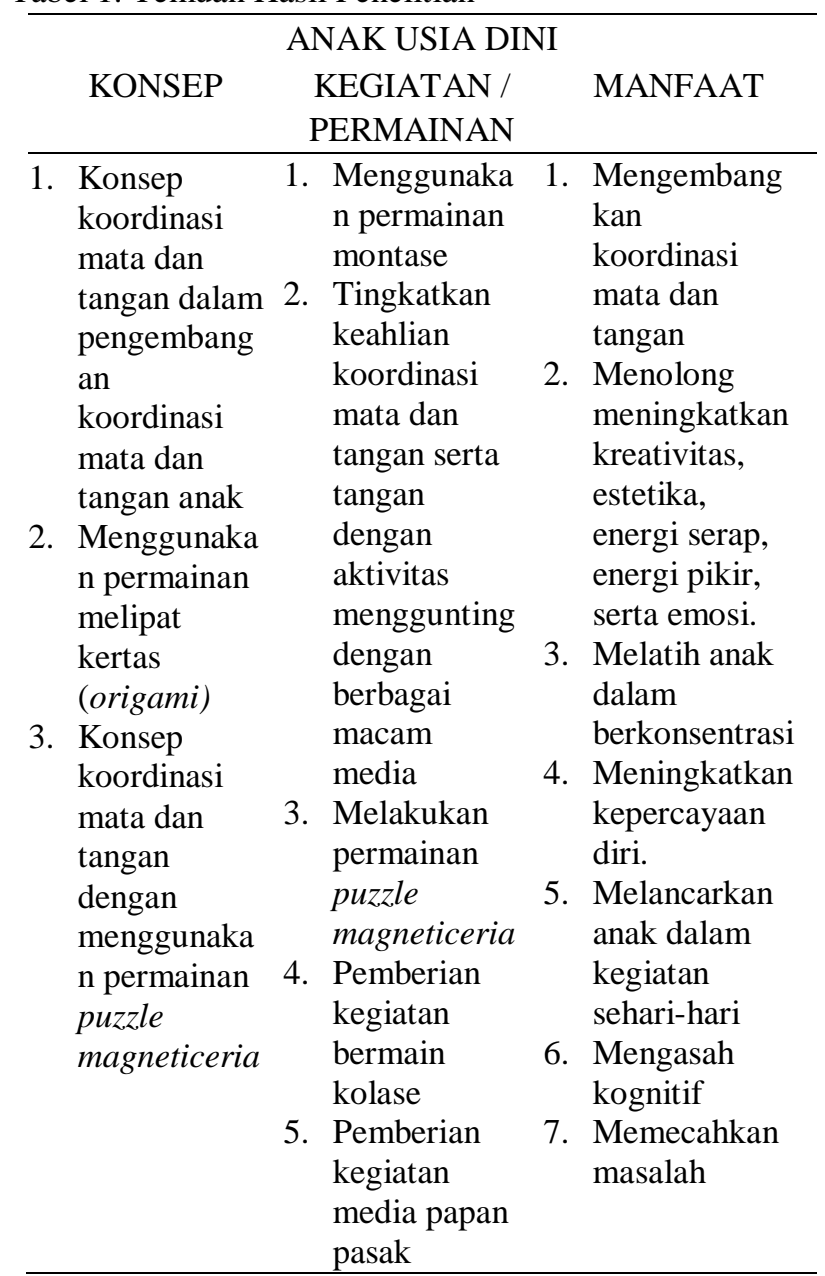

Secara keseluruhan, pada beberapa hasil temuan penelitian maka pada bagian ini akan di bahas pada penelitian yang telah didapatkan oleh peneliti dari beberapa temuan artikel, jurnal serta dokumendokumen yang terkait dengan hasil penelitian yang peneliti lakukan. Peneliti menujukkan dengan seiring jalannya kegiatan pembelajaran dalam mengembangkan koordinasi mata dan tangan anak usia taman kanak-kanak melalui beberapa kegiatan/ permainan yang diberikan oleh guru kepada anak. Terdapat dari beberapa hasil yang ditemukan dalam konsep pengembangan koordinasi mata dan tangan anak salah satu nya pada permainan puzzle magneticeria dari permainan tersebut guru sudah menemukan seperti apa konsep yang akan digunakan oleh guru dalam proses pembelajaran. Maka koordinasi mata dan tangan pada anak dapat tersalurkan dengan baik dan benar dalam permainan tersebut. Penelitian yang dilakukan oleh peneliti, peneliti mencari dan menganalisis apakah dalam permainan puzzle magneticeria merupakan sebuah konsep dalam pengembangan koordinasi mata dan tangan anak. Dari hasil yang peneliti dapatkan, pada permainan puzzle magneticeria membawa pengaruh pada perkembangan koordinasi mata dan tangan anak. 
Tidak hanya pada konsep pengembangan saja, perlu adanya kegiatan/permainan yang ditemukan agar konsep dalam mengembangkan koordinasi mata dan tangan anak dapat dilakukan. Kegiatan/ permainan koordinasi mata dan tangan memiliki bermacammacam bentuk kegiatan, seperti kegiatan pembuatan pewarna alami dari bahan alam. Dalam kegiatan ini anak diajak untuk membuat warna menggunakan bahan-bahan alami seperti: bahan dapur, bahan alam yang ada di daerah pedesaan, perkotaan dan pedesaan yang memiliki kekhasannya masing-masing, serta bahan sumber belajar dan alam (tanah, pasir dan daun). Dengan permainan ini maka perkembangan yang didapat oleh anak tidak hanya pada koordinasi mata dan tangan, tetapi pada kreativitas (seni), sosial emosional, kognitif, nilai agama dan moral yang dimiliki oleh anak.

Dalam kegiatan pastilah adanya sebuah manfaat, dari uraian di atas yang telah peneliti buat, manfaat yang didapat oleh anak adalah, anak bisa mensyukuri nikmat Allah yang telah diberikan dan menggunakan dengan sebaik-baiknya, tubuhnya kreativitas yang anak miliki, ada nya tingkat rasa sosial serta emosional anak dalam melakukan kegiatan/permainan tersebut, serta kuat nya daya ingat/ kognitif anak dalam kegiatan tersebut.

\section{SIMPULAN}

Berdasarkan hasil pembahasan dari analisis dalam beberapa artikel, jurnal di atas dapat disimpulkan bahwa pengembangan koordinasi mata dan tangan; Konsep koordinasi mata dan tangan anak adalah perencanaan atau rancangan yang dibuat dalam proses pembelajaran yang akan diberikan kepada anak. Dengan konsep maka guru mendapatkan gambaran bentuk kegiatan apa yang dilakukan. Contohnya: dengan penerapan metode melipat kertas (origami) dapat mengembangkan koordinasi mata dan tangan anak dan permainan puzzle magneticeria. Kegiatan/ permainan koordinasi mata dan tangan adalah bentuk kegiatan yang akan dilakukan dalam pengembangan koordinasi mata dan tangan anak. Dengan melakukan permainan akan membuat proses pembelajaran menjadi menyenangkan, tidak membosankan untuk anak agar anak tidak merasa jenuh dalam proses pembelajaran yang akan diberikan oleh guru, kegiatan yang dapat dilakukan seperti: permainan puzzle magneticeria terhadap kecerdasaan koordinasi mata dan tangan anak, memberikan permainan papan pasak, permainan Attack the Shark, serta permainan montase, Dengan menggunakan beberapa kegiatan atau permainan tentu adanya kegunaan atau manfaat pada kegiatan yang akan dilakukan atau diberikan, karena manfaat adalah suatu hal yang memiliki nilai guna yang dapat memberikan faedah. Contohnya, pada upaya tingkatkan keahlian keahlian koordinasi gerak mata serta tangan lewat aktivitas menggunting dengan bermacam berbagai media pada anak khasiatnya, terlatihnya konsentrasi pada anak, dengan berkonsentrasi koordinasi mata dan tangan anak akan berkembang dan bekerja dengan baik, dapat meningkatkan kepercayaan diri pada anak, dapat melancarkan anak dalam menulis, ungkapan ekspresi, serta mengasah kognitif anak.

Dengan konsep, kegiatan dan manfaat dalam pengembangan koordinasi mata dan tangan anak. Maka dengan begitu guru dapat mengetahui bagaimana permainan yang tepat dalam mengembangkan koordinasi mata dan tangan anak. Dengan menggunaka permainan yang dilakukan tentunya pada permainan memiliki rentang usia agar proses pembelajaran yang dilakukan tidak membuat anak kesusahan. Dan jika guru atau pendidik menerapkan langkahlangkah pada penggunaan pembelajaran dengan baik dan benar terhadap pembelajaran. Maka, pembelajaran akan menjadi lebih menyenagkan dan anak akan mengerti dan paham dengan proses kegiatan yang dicontohkan oleh guru. dan jika guru tidak memahami dengan metode kegiatan pembelajaran yang diterapkannya, maka anak juga tidak akan memahami kegiatan pembelajaran yang disampaikan oleh guru dan proses kegiatan pembelajaran tidak akan berjalan dengan optimal.

\section{DAFTAR PUSTAKA}

Agusmiati, S. (2019). Pengaruh Permainan Puzzle Magneticeria Terhadap Kecerdasan Koordinasi Gerakan Tubuh Dan Motorik Anak Di Paud Karya Galang Selebar Kota Bengkulu. Journal Of Early Childhood Islamic Education, 3(1), 242-250.

Dan, M., Pada, T., Di, A., Pradnyandari, T. K., Utara, K., \& Badung, K. (2020). Pemberian Kegiatan Bermain Kolase Meningkatkan Koordinasi. 4(2), 83-88.

Darmastuti, T. (2012). Meningkatkan Kemampuan Motorik Halus Anak Dalam Kegiatan Meronce Dengan Manik - Manik Melalui Metode Demonstrasi Pada Anak Kelompok a Di Tk Khadijah 2 Surabaya. 1(1), 2. https://dokumen.tips/documents/meningkatkankemampuan-motorik-halus-anak-dalamkegiatan-meronce-dengan-manik-manikmelalui-metode-demonstrasi-pada-anakkelompok-a-di-tk-khadijah-2-surabaya.html

Durotun Nihayah, 2019. (2019). IMPLEMENTASI MEDIA PEMBELAJARAN PAPAN PASAK UNTUK MELATIH KOORDINASI MATA DAN TANGAN DALAM MENGENALKAN HURUF HIJAIYAH PADA ANAK DIDIK DI RA NURUL HUDA RAJEKWESI MAYONG JEPARA.

Hasan, M. (2011). Pendidikan Anak Usia Dini.

Malika, T. T., \& Sutisna, N. (2017). Peningkatan 
Koordinasi Mata dan Tangan melalui Keterampilan Kirigami pada Siswa Cerebral Palsy Spastik di SLB D YPAC Bandung. JASSI ANAKKU, 18(1), 40-46. https://ejournal.upi.edu/index.php/jassi/article/vi ew/7656

Marselina, 2018. (n.d.). Universitas Sriwijaya PENERAPAN METODE MELIPAT KERTAS (ORIGAMI) DALAM PENGEMBANGAN FISIK MOTORIK HALUS ANAK KELOMPOK A DI TK ISLAM TERPADU KAYUAGUNG.

Martinis, Y., \& Sanan, J. (2010). Panduan Pendidikan Anak Usia Dini. In Gaung Persada (Vol. 5). http://katalog.kemdikbud.go.id/index.php?p=sho w_detail\&id=553218

Rasid, J., Wondal, R., \& Samad, R. (2020). Kajian Tentang Kegiatan Cooking Class Dalam Meningkatkan Keterampilan Motorik Halus Anak Usia 5-6 Tahun. Jurnal Ilmiah Cahaya Paud, 2(1), 82-91. https://doi.org/10.33387/cp.v2i1.2041

Rika Vira Zwagery, (2013). PERMAINAN ATTACK THE SHARK UNTUK MENINGKATKAN KEMAMPUAN MOTORIK HALUS YANG MENYANGKUT KOORDINASI.

Risaldy dan Meity (2014). (n.d.). Panduan Mengatasi Permasalahan Anak Usia Dini / Meity H. Idris, Sabil Risaldy; Desain Cover, Mukhlis Umar | Dinas Arsip dan Perpustakaan Kabupaten Bandung. Retrieved October 11, 2021, from http://perpus.bandungkab.go.id/opac/detailopac $? \mathrm{id}=6197$

Riza Armita Putri, 2019. (2019). MELALUI PERMAINAN LEMPAR TANGKAP BOLA PADA ANAK USIA 6 TAHUN Riza Armita Putri , 2 Yarmis Hasan Universitas Negeri Padang . Jln . Prof. Dr. Hamka Aia Tawa, Padang, 25131 , Indonesia . E-mail : Rizaarmitaputri3697@gmail.com.3(22), 76-80.

Rofiah, S. D., \& Mangkuwibawa, H. (2020). Upaya Meningkatkan Kemampuan Motorik Halus Anak Melalui Kegiatan Membatik Jumputan. (JAPRA) Jurnal Pendidikan Raudhatul Athfal (JAPRA), $3(1)$, 91-102. https://doi.org/10.15575/japra.v3i1.8109

Rosulillah, L. (2019). Peningkatan kemampuan motorik halus pada koordinasi gerak mata dan tangan anak melalui kegiatan Montase di Kelompok B RA Muslimat NU 65 Faqih Hasyim Siwalanpanji Buduran Sidoarjo.

Safdin, A., \& Mansor, N. (n.d.). Perkembangan Koordinasi Mata Dan Tangan "Kesediaan” Di Prasekolah: Isu, Cabaran, Amalan-Mengatasi Masalah Menulis. Retrieved October 11, 2021, from

https://www.academia.edu/5847419/PERKEMB ANGAN_KOORDINASI_MATA_DAN_TAN GAN_KESEDIAAN_DI_PRASEKOLAH_ISU _CABARAN_AMALAN_MENGATASI_MAS ALAH_MENULIS

Santoso, B. E. (n.d.). KONSEP DASAR PENDIDIKAN ANAK USIA DINI. Retrieved October 15, 2021, from

https://www.academia.edu/15683934/KONSEP _DASAR_PENDIDIKAN_ANAK_USIA_DINI

Saputra, Y. M., \& Ridyanto. (2017). Pembelajaran Kooperatif untuk Meningkatkan Ketrampilan Anak TK. Departemen Pendidikan Nasional.

Sukadiyanto, 2018. PERANAN LATIHAN OLAHRAGA TERHADAP PERKEMBANGAN OTAK. Jurnal Cakrawala Pendidikan, 1(1). https://doi.org/10.21831/cp.v1i1.4863

Sumantri, 2011. (n.d.). Metodologi penelitian kesehatan / Arif Sumantri | Perpustakaan UIN Sultan Syarif Kasim Riau. Retrieved October 11, 2021, from http://inlislite.uinsuska.ac.id/opac/detail-opac?id=4175

Tasnila. (2012). Meningkatkan Kemampuan Koordinasi Mata Dan Tangan Pada Anak Tunagrahita Sedang. Jurnal Ilmiah Pendidikan Khusus, 1(1), 172-182. http://ejournal.unp.ac.id/index.php/jupekhu

Whinda, T. (2014). UPAYA MENINGKATKAN KEMAMPUAN KOORDINASI GERAK MATA DAN TANGAN MELALUI KEGIATAN MENGGUNTING DENGAN BERBAGAI MEDIA PADA ANAK KELOMPOK AI DI TK ABA KARANGMALANG. 
